Diabetologia 9, $13-19(1973)$

C by Springer-Verlag 1973

\title{
Diabetic Coma: Serum Growth Hormone before and during Treatment*
}

\author{
K.G. Alberti and T.D. Hockaday \\ Nuffield Department of Medicine and Division of Medicine, Radeliffe Infirmary, Oxford
}

Received: August 28, 1972, accepted: October 26, 1972

\begin{abstract}
Summary. Serum growth hormone values in 37 patients with diabetic ketoacidosis wero $5.4 \pm 0.8 \mathrm{ng} / \mathrm{ml}$ (S.E.M.) in males and $6.7 \pm 1.1 \mathrm{ng} / \mathrm{ml}$ in fomales before treatment; while in five hyperosmolar non-ketotic patients the $\mathrm{HGH}$ concentration was $3.9 \pm 0.5 \mathrm{ng} / \mathrm{ml}$. One hour after insulin $90 \%$ of patients showed a rise in $\mathrm{HGH}$, to a mean of $33.7 \pm 9.8 \mathrm{ng} / \mathrm{ml}$ for males and $25.5 \pm 6.0 \mathrm{ng} / \mathrm{ml}$ for females in ketoacidosis; and to $27.1+9.9 \mathrm{ng} / \mathrm{ml}$ for hyperosmolar coma patients. The rise, which was transient, was inversely correlated with pretreatment plasma glucose, the $1 \mathrm{~h}$ plasma glucose concentration and plasma uroa, and directly proportional to the \% fall in blood glucose after $1 \mathrm{~h}$. When the ketoacidosis patients were
\end{abstract}

divided into two groups according to $H G H$ responso, those with a small response had the greater disturbances of plasma glucose, blood ketone bodies, blood lactate, plasma urea, blood $\mathrm{pH}$, and blood pressure, the smaller $1 \mathrm{~h}$ fall in blood glucose, and the higher mortality. Thus the most severely ketoacidotic patients had the poorest growth hormone response. Growth hormone is probably of little importance as an insulin antagonist in diabetic coma.

Key words: Diabotos, diabetic ketoacidosis, hyperosmolar non-ketotic coma, lactic acidosis, growth hor. mone, insulin, blood ketone bodies, free fatty acids, arterial $\mathrm{pH}$, plesma glucose.
The role of growth hormone in diabetes has been controversial since Young (1939) suggested it to be involved in initiation of the disease. More recently serum growth hormone levels have been found to be raised and to show great fluctuations in newly diagnosed and poorly-controlled juvenile diabetics in whom plasma FFA and blood glucose are raised (Hansen and Johansen, 1970; Johansen and Hansen, 1971).

In diabetic coma there is widespread disturbance of metabolic and endocrine homeostasis (Hockaday and Alberti, 1972). This paper describes measurements of serum growth hormone (HGH) during treatment of diabetic ketoacidosis and hyperosmolar, hyperglyc. aemic non-ketotic coma. Abnormal growth hormone values have been reported in diabetic ketoacidosis before treatment, with a rise one to two hours later, by both Cryer and Daughaday (1970) and Assan et al., (1969) although relatively normal pretreatment values were reported in most patients by others (Roth et al., 1964; Unger, 1965; Jacobs and Nabarro, 1969; Gerich et al., 1971; Sönksen et al., 1972). The cause of the elevated concentrations is unclear.

There is no agreed explanation for the lack of ketosis in hyperosmolar coma. One suggestion is that lipolysis is not increased, as it is in ketoacidosis, because of low or normal concentrations of serum cortisol and HGH (Gerich et al., 1971), while others postulate a block in hepatic ketone body production or the presence of sufficient insulin to restrain lipolysis (Johnson et al., 1968; Vinik et al., 1970). It is therefore important to compare HGH concentrations before and during treatment of both types of coma, and to see

* Presented in part at the Spring Moeting of the British Diabetic Association, York, April 1972. whether any metabolic parameter can be correlated with fluctuations in serum HGH values.

\section{Methods and Patients}

Plasma glucose (glucose oxidase Autoanalysor), potassium and urea were measured in the routine biochemical laboratory. Plasma free fatty acids (FFA) were measured colorimetrically (Itaya \& Ui, 1965). Blood 3-hydroxybutyrate and acetoacetate were measured enzymatically (Williamson et al., 1962) as was blood lactate (Hohorst et al., 1959). Serum growth hormone and serum insulin were moasurod by modifications of the double antibody radioirnmunoassay methods of Boden and Soeldner (1967) and Soeldner and Slone (1965) respectively. Frée-flowing venous blood samples were deproteinized or separated as described previously (Alberti and Hockaday, 1972).

The subjects comprised the forty six of the fifty nine patients admitted between June 1970 and February 1972 to the Radcliffe Infirmary in diabetic coma or precoma, as defined by Hockaday and Alberti (1972), on whom adequate serial sorum $\mathrm{HGH}$ measurements were available. Thirty scven had diabetic ketoacidosis, four had combined lactic and ketoacidosis, and five were in hyperosmolar non-ketotic coma. Of the ketoacidotics 23 were female and 14 male while only ono of the hyperosmolar coma patients was female. Six of the ketoacidotic patients were clinically obese: only one fomale $(70 \mathrm{~kg})$ weighed more than $65 \mathrm{~kg}$ and three males exceeded $70 \mathrm{~kg}(74,82$ and $97 \mathrm{~kg})$. Two ketoacidotic subjects had evidence of cirrhosis of the liver, as had ono lactic acidosis patient. Twenty of the ketoacidotic and four of the hyperosmolar coma patients were not proviously known to be diabetic. Nine of the ketoacidotic patients and one hyperosmolar patient were receiving insulin and seven were taking oral agents. Five patients with ketoacidosis died, two within the first $24 \mathrm{~h}$ of treatment (at $3 \frac{1 / 2}{2}$ and $17 \mathrm{~h}$ ). Details of patients are shown in Table 1.

Control subjects comprised either laboratory personnol ('normal' subjects) or newly diagnosed diabetics or known, 


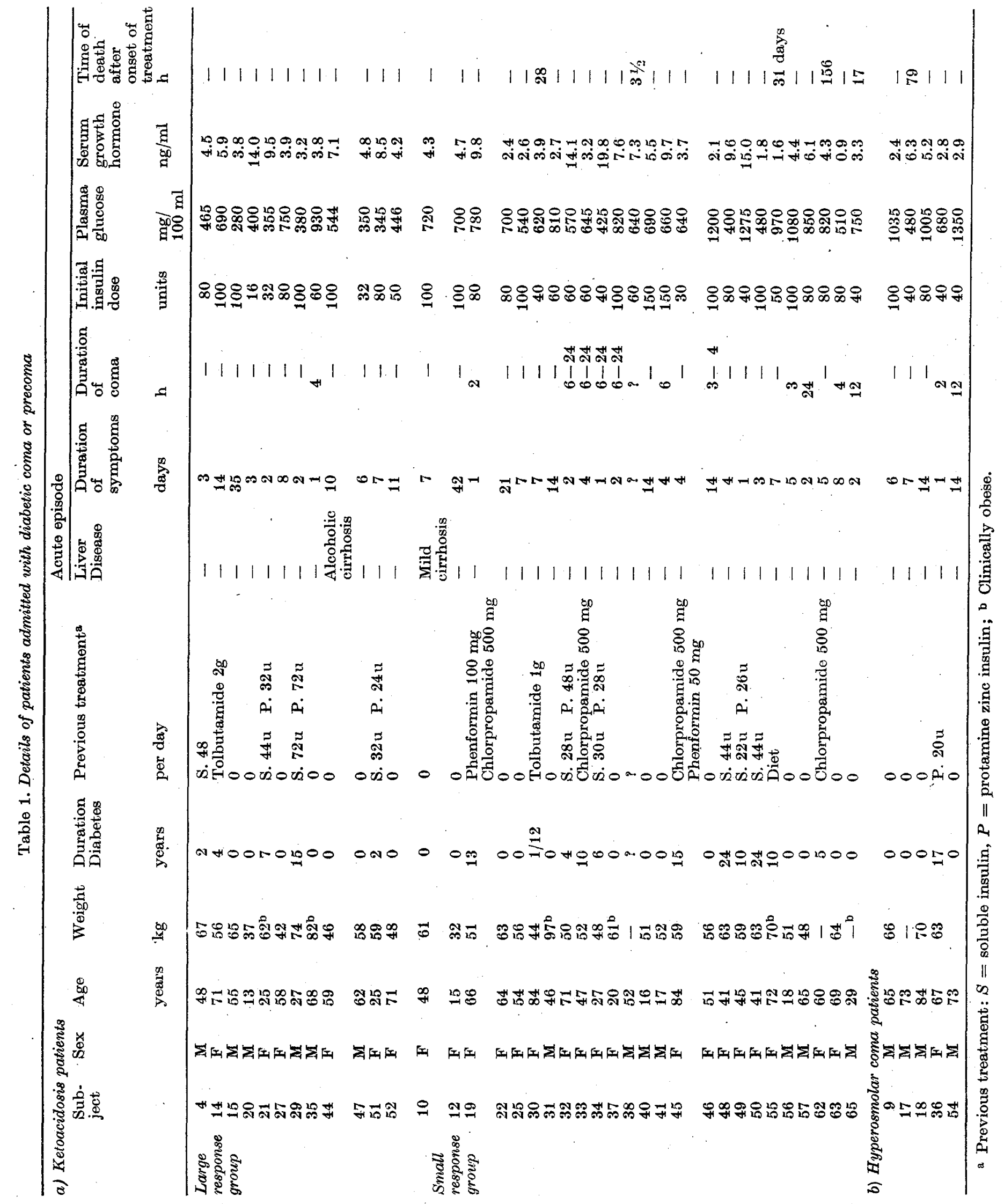


stable, insulin requiring diabetics fasted overnight. All samples from them were obtained through an indwolling venous catheter after 30 to 60 min recumbency. Statistical significanco was assessed by Student's t test.

\section{Results}

\section{Pre-treatment serum growth hormone concentrations}

The average pretreatment values of growth hormone for male ketoacidotics was $5.4 \pm 0.8 \mathrm{ng} / \mathrm{ml}$,com. pared with $2.5 \pm 1.4 \mathrm{ng} / \mathrm{ml}$ in control diabetics $(p<0.05)$ and $0.6 \pm 0.3 \mathrm{ng} / \mathrm{ml}$ in normal males $(p<0.01)$ (Table 2). In ketoacidotic females, however, values were the same as in normal or control diabetic females after an overnight fast. There was a wide scatter of values but only 4 ( 3 female and 1 male) of 37 exceeded $10 \mathrm{ng} / \mathrm{ml}$. $(n=27)$, those with high HGH values had a significantly lower $\mathrm{pH}(6.99 \pm 0.05 \nabla 7.19 \pm 0.03 ; p<0.005)$. Correlation of $\mathrm{pH}$ against pretreatment $\mathrm{HGH}$ gave an $r$ of $-0.32(p<0.10>0.05)$ with the correlation holding only in females $(r,-0.35)$. There was no correlation between pretreatment serum growth hormone concentrations and pretreatment plasma glucose, blood ketone bodies, blood lactate, plasma FFA, plasma potassium, plasma urea, calculated osmolarity, blood pressure, weight or age.

\section{Change in serum growth hormone concentration with treatment}

All but 4 of the ketoacidotic patients and all the hyperosmolar non-ketotic subjects showed a rise in serum growth hormone one hour after the first dose of insulin. There was no difference between males and

'Table 2. Serum growth hormone concentrations ( $\mathrm{ng} / \mathrm{ml}$ ) (土S.E.M.) during treatment of diabetic coma

\begin{tabular}{|c|c|c|c|c|c|c|}
\hline & & & $\begin{array}{l}\text { Pre- } \\
\text { treatment }\end{array}$ & $1 \mathrm{~h}$ & $5 \mathrm{~h}$ & $24 \mathrm{~h}$ \\
\hline \multirow[t]{2}{*}{ Normal } & Male & (16) & $0.6 \pm 0.3$ & - & - & - \\
\hline & Female & & $6.7 \pm 2.1$ & - & - & - \\
\hline $\begin{array}{l}\text { Control } \\
\text { diabotics }\end{array}$ & $\begin{array}{l}\text { Male } \\
\text { Female }\end{array}$ & $\begin{array}{r}(12) \\
(9)\end{array}$ & $\begin{array}{l}2.5 \pm 1.4 \\
5.5 \pm 2.0\end{array}$ & - & - & 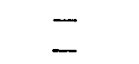 \\
\hline $\begin{array}{l}\text { Keto- } \\
\text { acidosis }\end{array}$ & $\begin{array}{l}\text { Male } \\
\text { Femalo }\end{array}$ & $\begin{array}{l}(14) \\
(23)\end{array}$ & $\begin{array}{l}5.4 \pm 0.8 \\
6.7 \pm 1.1\end{array}$ & $\begin{array}{l}33.7 \pm 9.8^{\mathrm{b}} \\
25.5 \pm 6.0^{\mathrm{b}}\end{array}$ & $\begin{array}{l}8.7 \pm 2.3^{\mathrm{a}} \\
5.4 \pm 0.8\end{array}$ & $\begin{array}{l}3.9 \pm 1.4 \\
3.1 \pm 0.4^{b}\end{array}$ \\
\hline \multirow{2}{*}{$\begin{array}{l}\text { Hyper- } \\
\text { osmolar } \\
\text { coma. }\end{array}$} & Male & (4) & $4.1 \pm 0.7$ & $31.7 \pm 11.3^{\mathrm{b}}$ & $7.5 \pm 2.3^{a}$ & $4.2 \pm 1.5$ \\
\hline & Total & (5) & $3.9 \pm 0.5$ & $27.1 \pm 9.9^{\mathrm{b}}$ & $6.8 \pm 1.9^{\mathrm{a}}$ & $3.7 \pm 1.2$ \\
\hline
\end{tabular}

\footnotetext{
a $p<0.05$ compared with pretreatment.

b $p<0.01$ compared with pretreatment; Numbers in parontheses indicate number of subjocts.
}

In the present study the mean serum HGH value for hyperosmolar coma patients was $3.9 \pm 0.5 \mathrm{ng} / \mathrm{ml}$ compared with the overall mean of $6.3 \pm 0.7 \mathrm{ng} / \mathrm{ml}$ for ketoacidotic patients. The mean value of the male hyperosmolar patients ( 4 of 5 ) was $4.1 \pm 0.7$ which was significantly higher than normal overnight fasted males $(p<0.001)$ but not significantly different from the male ketoacidotic patients.

Four patients had combined lactic acidosis and ketoacidosis. Pre-treatment values were 496.0, 14.4, 9.7 and $3.1 \mathrm{ng} / \mathrm{ml}$ while 2 diabetic subjects with normoglycaemic lactic acidosis had growth hormone concentrations of 287.5 and $8.6 \mathrm{ng} / \mathrm{ml}$. The two patients with the extremely high values both had liver disease as well as diabetes.

Correlation of pretreatment serum growth hormone concentration with blood metabolite values and other parameters in diabetic ketoacidosis

When patients with HGH values above $8 \mathrm{ng} / \mathrm{ml}$ $(n=9)$ were contrasted with those below $8 \mathrm{ng} / \mathrm{ml}$ females and the mean rises were similar to that found in the hyperosmolar group (Table 2). There was no correlation between the pretreatment value and the extent of the rise. At $5 \mathrm{~h}$ males were still higher than pretreatment while at $24 \mathrm{~h}$ values for both male and female ketoacidotic patients were significantly lower than for normal controls, but similar to diabetic controls. Interestingly, values for females tended to be lower than for males throughout the treatment period.

Hyperosmolar patients showed a similar trend and there was no significant difference between male hyperosmolar and ketoacidotic subjects at any time period. There was only one female hyperosmolar patient, and so separate sex analysis was not possible.

\section{Correlation of metabolic parameters with 1 h growth hormone response}

a) Plasma glucose. There was a strong negative correlation between pretreatment plasma glucose and the change in serum HGH found at $1 \mathrm{~h}$ after insulin 
$(r,-0.49 ; p<0.01)$ in the ketoacidotic patients. The correlation was weakened by inclusion of hyperosmolar patients $(r,-0.34 ; p<0.05)$. Thus the lower the initial glucose the greater the subsequent rise in growth hormone. This could not be attributed purely to insulin dosage as there was no correlation between this and HGH rise. Plasma glucose at $1 \mathrm{~h}$ also gave a negative correlation with rise in $\mathrm{HGH}(r,-0.52$; $p<0.01)$. Absolute fall in glucose showed only a loose
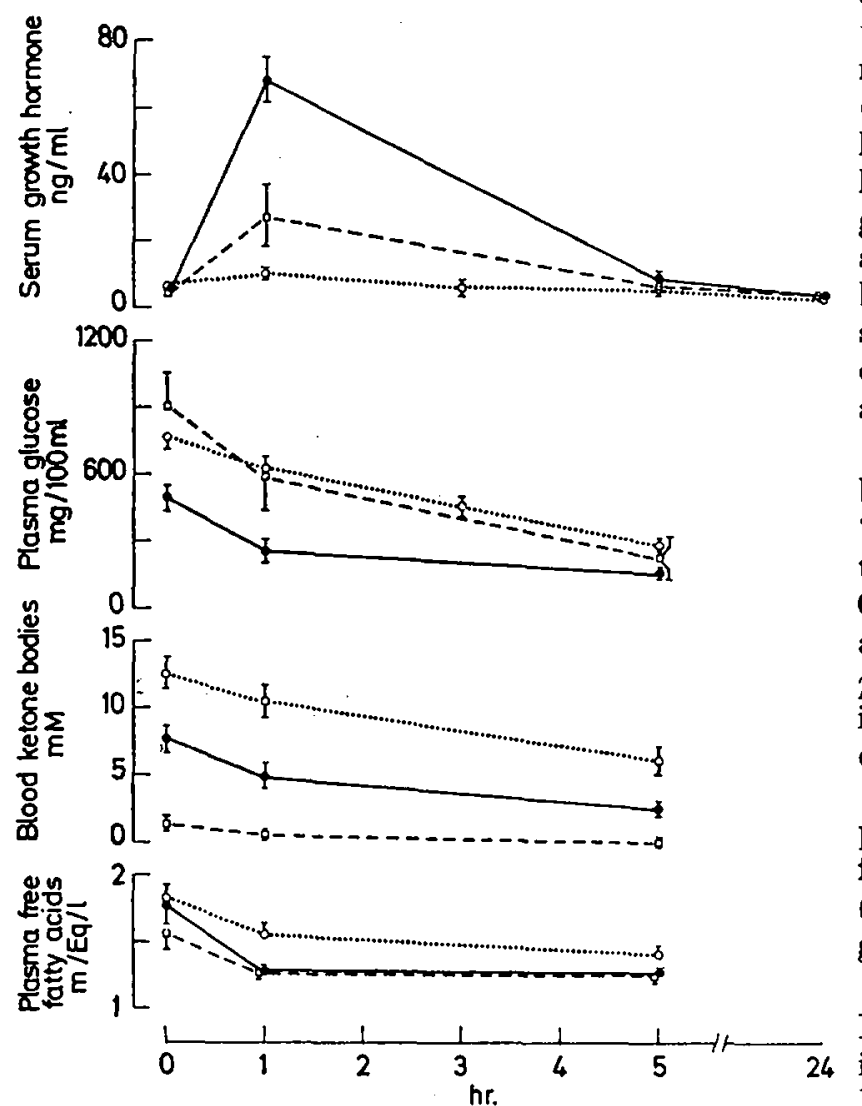

Fig. 1. Serum growth hormone, plasma glucose, plasma FFA and ketone bodies in diabetic coma. - -0 , ketoacidosis, "large risers"; o .... . ketoacidosis, "small risers"; $\square . . . \square$, hyperglyceemic non-ketotic patients. "Large risers" were those subjects with a rise in serum growth hormone of more than $30 \mathrm{ng} / \mathrm{ml}$ one hour after insulin; "small risers" had a rise of less than $30 \mathrm{ng} / \mathrm{ml}$

correlation with rise in growth hormone $(p<0.1>$ $0.05)$, although the correlation was better with $\%$ fall in plasma glucose at $1 \mathrm{~h}(p<0.01$ for ketoacidosis patients alone and $p<0.05$ for all patients).

b) Plasma urea. Surprisingly the change in serum growth hormone was related to the initial plasma urea concentration (but not the change in urea with treatment) for both ketoacidotics $(r,-0.50 ; p<0.01)$ and the whole coma group $(r,-0.45 ; p<0.01)$. Those subjects showing low initial plasma glucoses, biggest percentage fall in glucose and lowest pretreatment plasma urea were the ones who showed the biggest rise in plasma HGH one hour after treatment.

c) Other factors. 'There was no correlation between rise in serum growth hormone and pretreatment values or change in plasma FFA, blood ketone bodies, blood lactate and plasma potassium.

\section{Classification according to growth hormone response}

There was a wide variation in the magnitude of the rise in serum growth hormone concentration one hour after onset of treatment. The ketoacidotic patients were therefore divided into two groups: the "large response" group with a change of more than $30 \mathrm{ng} / \mathrm{ml}$ $(n=12)$ and the "small response" group with a rise of less than $30 \mathrm{ng} / \mathrm{ml}(n=25)$. Fig. 1 shows serum growth hormone values before and after treatment in the two groups. The hyperosmolar non-ketotic patients formed a third, intermediate group, two hyperosmolar subjects having large responses and three subjects small responses. Various metabolic characteristics have been compared in the two groups of ketoacidotic patients and the hyperosmolar nonketotic patients.

a) Plasma glucose. There was a striking difference between the two ketoacidotic groups (Fig. 1) with the "large response" group having significantly lower pretreatment glucoses $(494 \pm 57 \times 768 \pm 50 \mathrm{mg} \% ; p<$ 0.005 ), and larger $1 \mathrm{~h}$ fall in glucose, expressed both as $\mathrm{mg} / 100 \mathrm{ml}$ and as per cent fall $(47 \pm 7 \vee 18 \pm 3$; $p<0.001$ ). Plasma glucose was still significantly higher in the "small" response group $5 \mathrm{~h}$ after treatment commenced.

The hyperosmolar group with a higher initial plasma glucose showed a significantly greater absolute fall than the "smail" response group. The \% fall $(37 \pm 6)$ was intermediate between the two ketoacidotic groups, as was rise in serum $\mathrm{HGH}$.

b) Plasma FF A, blood ketone bodies and arterial $p H$. Fig. 1 shows also plasma FFA and blood ketone bodies in the 3 groups for the first $5 \mathrm{~h}$ following treatment. Plasma FF A showed no significant differences, although values tended to be higher throughout in the "small response" group. Blood ketone bodies were higher initially and at all subsequent times for the "small response" group while the hyperosmolar coma group had, by definition, low values throughout.

c) Serum insulin and insulin dose. There was a wide scatter of initial and one hour serum insulin concentrations when estimated in patients who had not previously had insulin therapy. Pretreatment values were $4.0 \pm 0.8$ and $7.9 \pm 1.4 \mu \mathrm{U} / \mathrm{ml}$ in the large and small response groups $(p<0.10>0.05)$ and at $1 \mathrm{~h}$ the values were $182.9 \pm 53.2$ and $649.2 \pm 209.7$ respectively (p, NS). The initial insulin dose for the two ketoacidotic groups and the hyperosmolar patients was similar $(69 \pm 9$ units for the "large response" group and $78 \pm 6$ for the "small response" group; $60 \pm 13$ for the hyperosmolar group).

d) Plasma urea, blood pressure and mortality. These 
parameters were chosen as indicators of the overall clinical severity of the cases. Table 3 shows that those subjects with the low HGH response had markedly higher pretreatment plasma urea concentrations and significantly lower blood pressures than the "large response" group. Nearly half of the "small response" group were comatose and this was associated with $20 \%$ mortality, while in the "large response" group there was only one comatose patient and no mortality. The hyperosmolar patients had higher blood pressures than the small responders although plasma urea was not different. There was no difference in the weights of patients, proportion of new diabetics or previous treatment in the three groups. other hand, Cryer and Daughaday (1971) in 4 of their 12 patients showed much higher pretreatment values, for which we have no explanation. They did however show a rise in HGH on treatment ir 9 of their patients, as did Roth et al. (1964) in 1 pr.tient and Sönksen et al. in their four patients (1972). The failure of other authors to note this rise was presumably because sufficiently early measurements after insulin were not made. Our results show that the main peak in HGH occurs early in treatment, not before one hour and not later than two to three hours (on the basis of multiple sampling in a few of our patients).

The pretreatment values in hyperosmolar non-

Table 3. Biochemical and clinical characteristics of patients in ketoacidosis (separated according to $H G H$ response to treatment) and in hyperosmolar nonketotic 'coma'

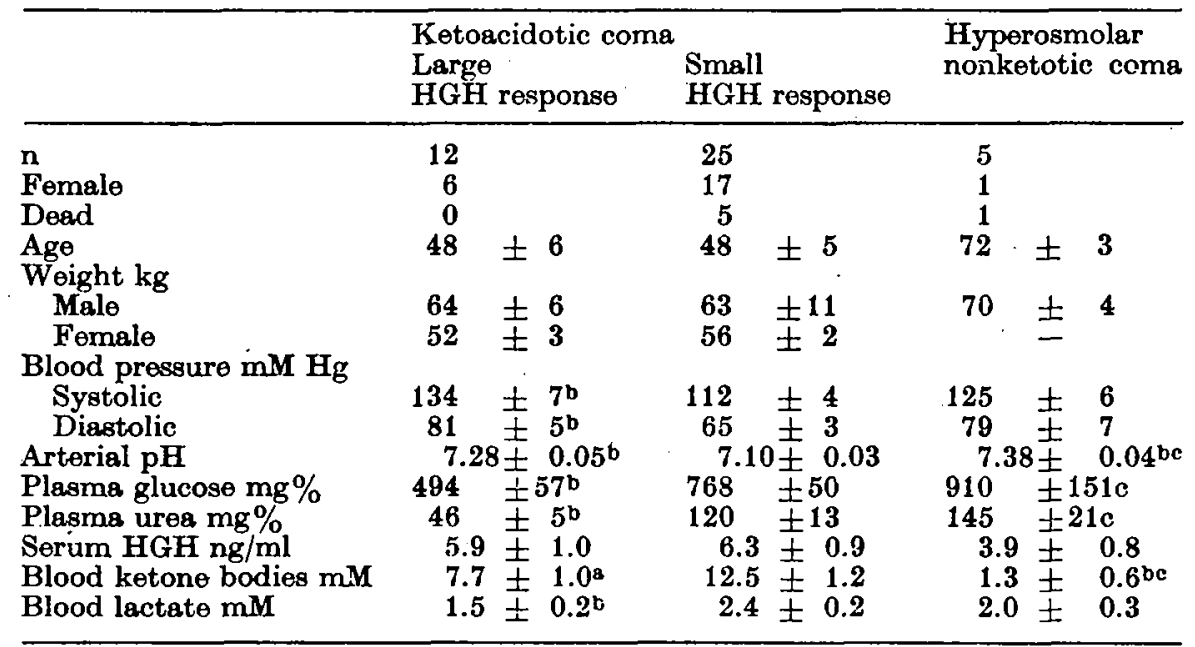

a $p<0.05$.

b $p<0.01$, compared with small HGH response group.

c $p<0.01$, compared with large HGH response group. The large HGH response group were those ketoacidotic patients showing a rise of greater than $30 \mathrm{ng} / \mathrm{ml}$ at $1 \mathrm{~h}$ after treatment began, the rest form the small HGH response group. All measurements were made before insulin treatment was commenced.

\section{Discussion}

The pretreatment growth hormone concentrations reported here for male ketoacidotic subjects follow the pattern of being higher than in normal or control diabetic subjects which one would predict from the results of Johansen and Hansen (1971). The deviation from control diabetics is smaller than would be expected, perhaps because of the opposing suppressive effect of hyperglycaemia (Roth et al., 1963). Comparisons are more difficult with the females because of the much greater variation in $\mathrm{HGH}$ which is known to occur among females.

The pretreatment serum HGH values are similar to those reported by Jacobs and Nabarro (1969), and Gerich et al., (1971). Sönksen et al., (1972) described values of less than $5 \mathrm{ng} / \mathrm{ml}$ but this was in only 4 patients and the sex of the patients is not stated. On the ketotic coma did not differ significantly from either control diabetics or ketoacidotic patients, particularly when sex was taken into account. Gerich et al. (1971) and Jacobs and Nabarro (1969) reported low HGH values in equivalent patients but did not allow for sex.

The diabetic ketoacidosis patients could be divided into two groups according to their growth hormone response one hour after insulin. The "small response" group formed a more severe group with respect to nearly all parameters studied.

We were unable to find a correlation between rise in $\mathrm{HGH}$ and fall in FFA, a known stimulus to $\mathrm{HGH}$ secretion (Irie et al., 1967; Quabbé et al., 1971). However, plasma FFA were higher in the "small response" group throughout the first $5 \mathrm{~h}$ of treatment and may well have exerted a depressive effect on HGH release in this group (Blackard et al., 1971). 
Uther circulating hormones may well have influenced growth hormone secretion in that plasma concentrations of cortisol (Jacobs and Nabarro, 1969), glucagon (Assan et al., 1969) and catecholamines (Christensen, 1972) may all be elevated and remain thus for several hours in severe ketoacidosis. Glucagon (Cain et al., 1970), and $\alpha$-adrenergic stimulation (Imura et al., 1968) both enhance growth hormone secretion, so these two factors cannot explain the decreased HGH in our more severe patients. However, Nakagawa et al., (1969) have shown dexamethasone suppression of insulininduced $\mathrm{HGH}$ release in normal males and this could be relevant to the present study. Plasma cortisol was measured in a few of our patients and tended to be higher in the "small response" group. Diminished total body potassium may also have played a role in that Podolsky et al. (1971) have shown that this is associated with a poor $\mathrm{HGH}$ response to arginine and insulin hypoglycaemia. Plasma potassium was not different in our two ketoacidotic groups, but it would seem reasonable to suppose that the more severe coma patients had the biggest total body potassium deficit.

The patho-physiological significance of these changes in growth hormone remains problematical. Growth hormone has a lipolytic effect in conjunction with cortisol (Fain et al., 1965; Goodman, 1968) and it has been suggested previously that growth hormone may contribute significantly to the lipolysis and consequent ketoacidosis of severe uncontrolled diabetes (Gerich et al., 1971). We would dispute that pretreatment $\mathrm{HGH}$ levels are sufficiently elevated to allow this, which is corroborated by the data of Sönksen et al., (1972). The transient nature of the HGH rise would also militate against a role of growth hormone in the continued elevation of blood ketone body concentration, as would our observation that the patients with largest growth hormone rises were those with the most rapid fall in blood ketone bodies. We would agree with Cryer and Daughaday (1970) who were unable to find a connexion between high growth hormone concentration and a poor glucose response to insulin, so-called "insulin resistance".

Madison, Luft and Seyffert (1969) have shown that growth hormone can inhibit gluconeogenesis in the dog liver in vivo while growth hormone is well known to have an acute enhancing effect on muscle glucose uptake (Park et al., 1952; Henderson et al., 1961), followed albeit by a delayed inhibitory effect. Thus, in the acute phase of treatment it could be argued that growth hormone secretion was beneficial and that the "large response" group show a larger absolute fall in blood glucose partly, perhaps, because of growth hormone release. This remains speculative.

Acknowledgements, We should like to thank the admitting physicians of the Radcliffe Infirmary for permission to study their patients, and the medical houso staff and the staff of the Dopartment of Clinical Biochemistry for their invaluable assistance; and Professor P.B. Beeson for his advice and encouragement. We are particularly grateful to Dr. D.H. Williamson for his continual advice and help, and to Miss $H$. Kuresova, Miss S. Warne and Mrs. V. Ilic for technical assistance. K.G.M.M.A was supported by the Wellcome Trust and grants in aid from the British Diabetic Association and the National Health Service are gratefully acknowledged.

\section{References}

Alberti, K.G.M.M., Hockaday, T.D.R.: Rapid blood ketono estimation in the diagnosis of diabetic ketoacidosis. Brit. med. J. 1972 II, 565-568.

Assan, R., Hautecouverture, G., Guillemant, S., Dauchy, F., Protin, P., Dérot, M.: Evolution de paramètres hormonaux (glucagon, cortisol, hormone somatotrope) et énergétiques (glucose, acides gras, glycerol libre) dans dix acido-cetoses diabotiques graves traitées. Path. Biol. 17, 1095-1105 (1969).

Blackard, W.G., Hull, E.W., Lopez, S. A. : Effect of lipids on growth hormone secretion in humans. J. clin. Invest. 50, $1439-1443$ (1971)

Boden, G., Soeldner, J.S.: A sensitive double antibody radioimmunoassay for human growth hormone (HGH): Levels of $\mathrm{HGH}$ following rapid tolbutamide infusion. Diabetologia 3, 413-421 (1967).

Cain, J.P., Williams, G.H., Dluhy, R.G.: Glucagon stimulation of human growth hormone. J. clin. Endocr. $31,222-224(1970)$.

Christensen, N.J.: Plasma noradrenaline and adrenaline in untreated diabetics, during fasting and after insulin administration. (Submitted for publication).

Cryer, P.E., Daughaday, W.H.: Diabetic ketosis. Serial plasma growth hormone concentrations during therapy. Diabetes 19, 519-523 (1970).

Fain, J.N., Kovacev, V.P., Scow, R.N.: Effect of growth hormone and dexamethasone on lipolysis and metab. olism in isolated fat cells of the rat. J. biol. Chem. 240, $3522-3529$ (1965).

Gerich, J.E., Martin, M.M., Recant, L.: Clinical and motabolic characteristies of hyperosmolar nonketotic coma. Diabetes 20, 228-238 (1971).

Goodman, H.M.: Effects of growth hormone on isolated adipose tissue. Proceedings of the First International Symposium on Growth Hormone. Fd. A. Pecile and E.E. Müller, Excerpta Medica Intern. Congr. Ser. 158, $153-171$ (1968).

Hansen, Aa. P., Johansen, K.: Diurnal pattorns of blood glucose, serum free fatty acids, insulin, glucagon and growth hormone in normal and juvenile diabetics. Diabetologia $6,27-33(1970)$.

Henderson, M.J., Morgan, H.E., Park, C.R.: Regulation of glucose uptake in muscle. 5. The effect of growth hormone on glucose transport in the isolated, perfused rat heart. J. biol. Chem. 236, 2157-2161 (1961).

Hockaday, T.D.R., Alberti, K. G.M.M.: Diabotic coma. Endocr. Metabol. Clin. 1, $751-788$ (1972).

Hohorst, H. J., Kreutz, F.H., Bücher, T.H.: Úber Meta bolitgehalte und Metabolitkonzentrationen in cler Leber der Ratte. Biochem. Z. 332, 18-46 (1959).

Imura, H., Kato, Y., Ikeda, M., Morimoto, M., Yawata, M., Fukase, M.: Increased plasma lovels of growth hormone during infusion of propanalol. J. clin. Endoer. 28, 1079-1081 (1968).

Irie, M., Sakuma, M., Tsushima, T., Shizume, K., Nakao, K.: Effect of nicotinic acid administration on plasma growth hormono concentrations. Proc. Soc. Exp. Biol. Med. 126, 708-711 (1967).

Itaya, K., Ui, M.: Colorimetric determination of free fatty acids in biological fluids. J. Lipid Res. 6, 16-20 (1965).

Jacobs, H.S., Nabarro, J.D.: Plasma 11-hydroxycorticosteroid and growth hormone levels in acute medical illnosses. Brit. Med. J. 1969 II, 595-598. 
Johansen, K., Hansen, Aa.P.: Diurnal serum growth hormone in poorly and well-controlled juvenile diabetics. Diabetos 20, 239-245 (1971).

Johnson, R. D., Conn, J. W., Dykman, C. J., Pek, S., Stam, J.I.: Mechanism and management of hyperosmolar coma without ketoacidosis in the diabetic. Diabetes 18 , 111- 116 (1969).

Madison, L.L., Luft, R., Seyffert, W. A., Jr. : Acute effect of physiologic and pharmacologic doses of growth hormone on hepatic glucose output and peripheral glucose utilisation. In Protein and Polypeptide. Hor. mones. Ed. M. Margoulies, Excerpta Medica, Int. Cong. Ser. 161, 529-538 (1969).

Nakagawa, K., Horiuchi, Y., Mashimo, K.: Responses of plasma growth hormone and corticosteroids to insulin and arginine with or without prior administration of dexamethatone. J. clin. Endocr. 29, 35-40 (1969).

Quabbé, H.J., Elban, K., Siegers, U., Bratzke, H.J.: Studies on a possible foedback mechanism between plasma fatty acid concentration and human growth hormone. Proceedings of the second International Sympolium on Growth Hormone. Excerpta Medica, Int. Congr. Ser. 236, 59 (1971).

Park, C.R., Brown, D.H., Cornblath, M., Daughaday, W.H., Krahl, M.E.: The effect of growth hormone on glucose uptake by the isolated rat diaphragm. J. biol. Chem. 197, 151-166 (1952).

Podolsky, S., Burrows, B.A., Pattavina, C.: Effect of chronic potassium depletion on growth hormone release in man. Proceedings of the Second International Symposium on Growth Hormone. Excerpta Medica, Int. Congr. Ser. 236, 50 (1971).
Roth, J., Glick, S.M., Yalow, R.S., Berson, S. A.: Secretion of human growth hormono: Physiologic and experimental modification. Metabolism 12, 577-579 (1963).

Roth, J., Glick, S.M., Yalow, R.S., Jerson, S.A.: Influence of blood glucose on the plasina concentration of growth hormone. Diabotes 13, 355-361 (1964).

Soeldner, J.S., Slone, D.: Critical variables in the radioimmunoassay of serum insulin using the double antibody technic. Diabetes 14, $771-779$ (1965).

Sönksen, P.H., Srivastava, M.C., Tompkins, C., Nabarro, J.D.N.: Growth hormone and cortisol responses to insulin infusion in patients with diabetes mellitus. Lancet 1972 II, $155-160$.

Unger, R.H.: High growth hormone levels in diabetic ketoacidosis. J. Amer. med. Ass. 191, 945- 947 (1965).

Vinik, A., Seftel, H., Joffe, B.I.: Metabolic findings in hyperosmolar, non-ketotic diabetic stupor. Lancet 1970 II, $797-799$.

Williamson, D.H., Mellanby, J., Krebs, H. A.: Enzymic determination of $\mathrm{D}(-) \beta$-hydroxybutyric acid and acetoacetic acid in blood. Biochem. J. 82, 90-96 (1962).

Young, F.G.: The relationship of the anterior pituitary gland to carbohydrate metabolism. Brit. Med. J. 1939 II, $393-396$.

K. G. Alberti, D. Phil.

Nuffield Dept. of Medicine

Radcliffe Infirmary

Oxford

England 